\title{
Training Teachers of Rural Science
}

TN 1937 the University of Reading Education Department, under the direction of Prof. H. C. Barmard, decided to pay special attention to training teachers for posts in rural senior, central and secondary schools. Three main considerations seemed to make this undertaking a desirable feature of the training course : (1) there was likely to be a considerable and increasing demand for teachers who could teach science with full reference to the rural environment; (2) the University of Reading has a well-organized faculty of agriculture and horticulture; (3) there are in the surrounding countryside several schools which make a speciality of teaching rural subjects.

In instituting the course at Reading, the principle was adopted that it is undesirable to train teachers so narrowly in one aspect of education that they are partially unfitted to see any other aspect. The course in the teaching of rural science was therefore made one of a number of optional subjects, and at present it includes : $(a)$ a series of lectures on general aspects of rural education; (b) occasional lectures by teachers and others actively engaged in rural education ; $(c)$ visits to rural schools ; $(d)$ teaching practice in rural schools; (e) practical instruction in horticulture and handicrafts.

The lectures deal with such topics as: the meaning of rural education; comparison of rural and urban schools; Hadow and Spens reorganization in country areas and their implications; the approach to knowledge through practical activities, for example, how the garden can become the centre of a curriculum which differs from the 'normal' only in the principles on which it is devised and the way in which it is developed; the value and the conduct of school expeditions to farms, etc., and the aims, staffing, equipment and finance of gardening, livestock keeping and handicrafts. Special lectures have been given by the head master of a second- ary school with a strong 'agricultural bias', by one of His Majesty's inspectors of schools who specializes in rural science and by a horticultural organizer to a county council.

Visits to rural schools, when students have been well prepared in what to look for, have proved to be very valuable, and teaching practice in rural schools has been arranged.

Students receive practical instruction in horticulture at the University Horticultural Station. Their work includes preparation of ground, planting, propagation, pruning, erop rotation, managing a small greenhouse or a frame, grafting, etc. In handicrafts, students are encouraged to make apparatus useful for rural activities, such as model greenhouses, cold frames, etc. A short course in metal-work is being developed, in which students may make such things as gate latches, simple agricultural tools, etc.

The course, as at present constituted, is in its infancy, and is in no way static. Some developments which are contemplated are : contact with a senior school within easy distance of the University; a 'model' garden; instruction in livestock keeping; visits to the University farm; and lectures by farmers.

This then is one way in which Reading is trying to help to forge the rather weak link between education and agriculture.

Students of the University of Reading who have graduated in science or agriculture or horticulture, and who have afterwards spent a year in preparation for the education diploma, including the course on teaching rural science, should be well fitted to teach in a rural school of any type. The University Department of Education already conducts, at the request of the Ministry of Agriculture, a fortnight's course in the "Technique of Teaching" for those who hold posts on the agricultural staff of a county authority or similar positions.

\section{Wave-Action and Shore-Lines}

A $\mathrm{N}$ article by Mr. W. V. Lewis on the "Evolution A of Shore-line Curves" (Proc. Geol. Ass., 49, Pt. $2 ; 1938$ ) is a valuable contribution to a well-worn subject. The author's position is fundamentally that of Sir Henry de la Beche, founder of the Geological Survey, who a hundred years ago stressed the importance both of the longshore drift of material by prevalent waves and the independent action of storm or dominant waves in piling up embankments of detritus in the direction of the greatest force, sometimes at right angles to the shore. In later years opinions changed, and explanation of the evolution of coastal outline was purely on the action of longshore and eddy currents. Latterly, however, there has been a revival of the wave-action hypothesis due largely to the findings of the Royal Commission on Coast Erosion and Afforestation and the work of Steers, Johnson, and others. Mr. Lewis proceeds to examine in detail various sections of coastline in Britain on the Moray Firth, Cardigan Bay, Bristol Channel, Isle of Purbeck and Chesil Bank, and suggests that shore curves, far from being explicable only by reference to longshore currents, yield in certain cases readily to analysis in terms of the direction of approach of both dominant and prevalent waves, especially the former.

The case of Weymouth Bay and Chesil Bank is of particular interest. It appears that breakwaters in connexion with the Portland Harbour works have caused a modification in the direction of wave approach, with the result that shingle which used to be driven north from Weymouth is now accumulating in front of the town. This means that the bay has swung slightly round so as to face a more easterly direction. As regards the Chesil Bank, it is pointed out that along its sixteen miles from Chesilton to West Bay we have one of the most perfect examples in the British Isles of a shore moulded into line with both dominant and prevalent waves. This gives stability to the curve of the Beach, which exactly faces the direction of open water just clear of Start Point and Ushant into the Atlantic. The grading of the shingle, which increases steadily in size from West Bay to Chesilton, is held to indicate that there is now no permanent drift of material in either direction. In any case the Beach could not have been formed by simple longshore drift, as this would have first filled up the narrow backwater behind. 